\title{
The Revelation from Sun Shaoping's Career Development Course in Novel Ordinary World for Contemporary College Students
}

\author{
Kai Zhao \\ School Office, South China University of Technology, Guangzhou, China \\ 52871076@qq.com
} Keywords: College Students, Employment View, Sun Shaoping, Novel Ordinary World, Three -
Change.

\begin{abstract}
This article lists career development course of youth Sun Shaoping who is the protagonist of novel Ordinary World. We discussed effects of reform and opening up policy, family life, and personal value on his career, and pointed out that contemporary college students should strengthen their mind, overcome limitations and improve ability so as to form a correct employment view.
\end{abstract}

\section{Introduction}

The novel "Ordinary World" [1] shows the vicissitudes of society before and after the reform and opening up policy from 1975 to 1985 and the growth of the characters. Although the backgrounds of the times are different and the levels of education are different, everyone needs the same selffulfillment. The image of Sun Shaoping, a young man who worked hard at the age of 17-27 and finally found his life goal, is deeply rooted in the hearts of readers. The course of his career development has important educational significance to the cultivation of the contemporary college students ' employment concept.

\section{2. "Three Changes" in Sun Shaoping's Career Development}

The ordinary world depicts Sun Shaoping's development process of "three changes" in different stages of professional consciousness in his youth. That shows a very vivid time color and typical significance. "When reform and opening up policy achieved initial success, the community of interests initially formed, everyone else finds a 'sense of belonging' among them, but Sun Shao-ping has succeeded in developing a rich subject in the constant state of giving up himself. " [2] The "three changes" of his career are also the "three changes" of his life, what makes him career goals become clearer, social understanding is more mature, the spiritual world is richer.

\subsection{Career Awareness Loss Stage: From Teaching At Home to Leaving To County Town}

After failing the College Entrance Exam, Sun Shaoping's only career choice was to teach in a small village school near his home. When "the earth-shaking changes took place in the village and at home". "Three years of teaching career ended so that he had to go home and become a peasant" (Part II , Page 87). As Sun Shaoping received high school education, he surpassed traditional peasants' values. "After continuous inner struggle, Sun Shaoping has determined to leave his village and go outside to get into the world" (Part II, p. 90). From rural areas to cities is "a great awakening of a youth's sense of self-consciousness" (Part II, p. 87), the stubborn personality in his bones made him try hard to change from being forced to accept, but "he questioned himself in his heart"(Part II, p. 96). Although he did not have excellent skills, clear goals and sound plans, and the professional awareness was at a loss, the significant choice of "leaving the village" enabled him to make a transition in his career area from rural areas to county towns.

\subsection{Career Development Embryonic Stage: From TEMPORY Workers to FORMAL Workers}

Sun Shaoping settled tentatively in the county market and initially solved the problem of food and clothing. He transferred his registered residence from the rural areas to the suburbs with friend's help. However, the reality was that he was only a passerby, and he realized that short-term employment was "a very unreliable way of making a living"(Part II, p. 163). Just then, his friend once again helped 
him obtain the opportunity to enter the mine factory as a staff. When Sun Shaoping transferred his registered residence from rural to urban and became a coal mine worker as a stable job, his understanding of career gradually sprouted. This also led to a gradual shift in career status from drift to stability.

\subsection{Career Development SELF-CONSCIOUS Stage: From Passive Selection to Active}

The working environment for coal miners is extremely tough and dangerous. However, in Sun ShaoPing's opinion, "as long as there is a formal job, he will go even to the hell" (Part II, p. 412). Work in the coal mine is relatively stable and has a considerable income, but also with his own efforts became miners team leader, has won the respect of others, the coal mine site has become a place where great wealth can be created, an exciting stage for life(Part III, p. 14). And he begins to determine a long-term career development plan and prepares to apply for a coal technology school. Even he had an opportunity to transfer to provincial capital work, he resolutely refused. Instead, "He returned to Daya Bay Coal Mine, then he heard the vivid song of a whistle blowing down in his ear, a song that praised youth and life" (Part III, p. 419). At this stage, Sun shaoping has strong identity with coal mine worker, and realizes life value gradually. In his opinion, "in this world, only man's labor and creation are the most proud" (Part III, p. 349). He regarded taking root in the coal mine as a lifelong career and realized the transition from passive employment to active selection.

\section{The Reasons for "Three Changes" of Sun Shaoping's Career}

During the career development of "Three changes" of young Sun Shaoping, he was not only impaired in objective factors such as the age of growth and the family of his life, but also his understanding of the world was invisiblely influenced by the objective environment, but he constantly shackled the objective environment, take the initiative to change his own destiny.

\subsection{The Flood of Reform and Opening Up Policy in The Great Era}

The ordinary world reflects the change of thoughts, spirit and temperament of Chinese rural society and its characters in the early stage of reform and opening up. "The thought of the change of the era of the 1980s is the beginning of the May Fourth Movement enlightenment, and the essence of enlightenment is to call people out of the bondage and oppression of religious ideology, rejoin the secular world, reknow human and humanity itself." [3] The early stage of reform and opening up has influenced the career development of Sun Shaoping. On the one hand, he is full of imagination and longing for a good life, and the reform and opening up policy allowing free movement of population makes him restless. On the other hand, the social problem of reform and opening up and the dual structure of urban and rural areas is deep-rooted, and the rural aspirants have to either receive education or work if they want to jump out of the rural areas. Sun shaoping, who failed the college entrance examination, could only choose to work in the city, although he did his best to "completely betray the narrowness of farmers and pursue higher life significance" (part 2, page 326). However, the social role of ordinary workers is unlikely to involve him in the torrent of social development.

\subsection{Restrictions on The Conditions of Poverty In Small Families}

The near-collapse of Sun Shaoping's family economy contributes to his high self-esteem and deformity, "The most painful thing is the harm done to self-esteem by poverty" (part 1, page 7). Living conditions forced him to quickly become a strong self, changing the poor family image in rural areas. On the one hand, the family economy forces Sun Shaoping to be a powerful man fastly. He bears the expectations of his family and the pressure of himself to make contributions to the family as an important indicator of the value of life. Family education, on the other hand, limited Sun Shaoping's career vision, he had no social relationship, can't obtain ideal career independently, and can't easily leave coal plants, which have restricted the development of his career.

\subsection{The Pursuit of Ideal Life Value of Ordinary People}

According to the general theory of career planning, the subjective factors that influence career are: interest, ability, character and values. Sun Shaoping cannot choose a career by interest or ability, but can only depend on his character and values. The lack of material and mental anguish left Sun Shaoping have no choice but to endure hardships. "Even if it is more bitter than the peasant, as long as he lives his life like a man, he is satisfied" (Part II, page 88). Reading in the first stage, alleviate 
the pressure from life due to poor families, in the second and third stages, the pain of the body eliminate mental pressure. And of course, passion, concentration, responsibility and other personalities, as well as values of freedom, independence and integrity have a significant impact on his career choices.

\section{Revelation for Nowadays College Student's Career view of Sun Shaoping's Three Changes}

Sun Shaoping hasn't accept high education and can't compete with others, but he has unique quality. One is perseverance, second is naivety, third is idealistic feelings. His life value is positive and optimistic, that is enlightenment for contemporary college students especially in such a rat race.

\subsection{Using three JUDTICE response two contradiction of employment situation}

There are two contradictions of employment market, one is more and less, the number of college graduates is 7,950,000 in 2017, creats greatest of history, but employment demand rose less. Another is between high demand from employer and college stdents' low skill. Face to this two contradictions, college students should straighten the employment mentality, and adjust themselves.

Prepare to know the employment market, and forget thinking of finding a high salary at beginning, third is adjust ordinary way of employment to mass entrepreneurship, mass innovation the new strategy, expend the skill. To adjust the "favored" employment mentality, psychological preparedness in advance to do a job, take the initiative to adapt to the job market, second is adjust the eyes of highlevel career ideas, third is adjust the conventional way of employment, adapt to the national policy of "public entrepreneurship and innovation", expand employment and entrepreneurship, and achieve higher quality and more full employment.

\subsection{Using three ABANDON surmount two effectives from family condition}

Can not be ignored is family background has become a part of college students employment invisible security. For poor college students, should try to overcome the impact of ordinary family employment with less resources. The study shows that "the more family-owned economic resources, cultural resources, and organizational resources, the easier it is for them to find better and more stable starting positions in their initial employment" [4]. Parents of economically disadvantaged families can not pave the way for their children's employment. And to overcome the poor quality of employment brought about by economic poverty. Due to acquired less training and other reasons, the economically disadvantaged students perform generally in terms of coordination, communication and reflection, resulting in the relatively common phenomenon of low employment rate and low starting salaries.

Sun Shaoping has a poverty family, but through his persistence of ideals and earnestness in labor, he obtained a steady and satisfactory job. Nowadays students should overcome difficulties, to abandon the impact of the family environment, but always carry the ideal of occupation, so that employment back to the nature of education. Abandon the impact of family education, through targeted learning skills, to participate in extra-curricular activities such as internship practice, take the initiative to increase learning opportunities to make up for shortages due to lack of education or training. Abandon the impact of family resources, take the initiative to expand social resources, broaden their horizons knowledge, comprehensive analysis of employment and entrepreneurship policies, to provide better employment.

\subsection{Using the Three MUST to Improve Shortage of Personal Qualities}

From Sun Shaoping, we can clearly see that he found himself in career development. Contemporary college students have the basic expertise and richer career optional possibilities, but because of the influence of surrounding environment and the growth experience, so compared with Sun Shaoping, there are "two less" obviously. One is less of persistent pursuit of the spirit and tenacity, another is frustrated ability, compressive ability, and lack of hard-working ability.

The contemporary college students should do "three must" upgrade ability to get a good job, one must have a clear self-awareness, use Holland personality and occupation Type said, MBTI Professional personality test aids and other tools, explore their interests, abilities, personality and values, choose the most suitable for their careers. Second, there must be a strong psychological presupposition, in the process of choosing a career to comply with the heart, get frustration 
preparation. Third, it is necessary to gradually clear career planning from action, only to find their own position and overcome the difficulties in the job, so that the job satisfaction will be higher, longer lasting, more competitive.

\section{References}

[1].Yao LU. Ordinary World[M].Beijing: Beijing October Arts and Literature Publishing House, 2012

[2].Li Jin. In times conflict and in the depths of trouble: Look back at Sun Shaoping[J]. Beijing: Literary Review, 2012(5):p.136-142

[3].Xin Han. Generation and transcendence: The ordinary world and the spirit of the 1980s[J]. Beijing: The Chinese soul, 2013(1):p.22-24

[4]. Li-yu ZHANG. Study on the Relationship between College Graduates' Employment and their Family Background - - a research based on a group of college graduates[G]. China University Students Career Guide, 2013(4):p.14-18 